\title{
Space. Urban, Rural, Territorial
}

\author{
Martina Löw
}

\begin{abstract}
Starting from a relational concept of space, Martina Löw discusses findings in spatial sociology on the basis of modernity's foremost spatial types-namely, the city and the territory-and fundamental relational opposites (urban-rural; timespace; territory-fluid space). She gives an overview of current sociological debates in Germany with a special focus on the sociology of knowledge. The article considers research on the intrinsic logic of cities as well as recent concepts dealing with the dynamization of spatial relations. One major hypothesis is that the constitution of space today is characterized by a network of interdependencies formed by processes of translocalization and polycontexturality, overwriting or undermining traditional territorial spatial structures, which remain nonetheless relevant.
\end{abstract}

Keywords: Communicative action, place, city, space, social change

\section{Introduction}

Space is constitutive for social processes. In the twentieth century, sociologists have been continually engaged with the consequences for sociological theory-building as well as empirical investigation that would necessarily result from this proposition (initially Simmel, 1997 [orig. 1903]; or Durkheim, 1915; later, e.g., Lefebvre, 1991 [orig. 1974] and Giddens, 1984). However, compared with time or the physical body, space has played a subordinate role in the sociologies of many societies or in "international" sociological debates. ${ }^{1}$ Within German-language sociology, this peripheralization of spatial theory has shifted substantially during the 21st century. ${ }^{2}$

Space is generally understood as a relational arrangement of living beings and social goods in places (Löw, 2016; orig. in German 2001). Space is produced through the placing ${ }^{3}$ of social goods and through acts of synthesis (goods and people are amalgamated to spaces by way of processes of perception, imagination, and memory). The following contribution begins by presenting areas of inquiry in spatial sociology

Note: Translation from German, including all quotes from German literature, by David Haney for SocioTrans-Social Scientific Translation \& Editing.

1 An exception is French sociology in the twentieth century (see, e.g., Bourdieu, 1977; Lefebvre, 1991; Rémy and Voye, 1981; Foucault, 1991 [orig. 1975]; on French sociology, also Delitz, 2017; Löw, 2018). 2 Further development of this essay was supported by the Deutsche Forschungsgemeinschaft (DFG) in connection with the Collaborative Research Center 1265, Re-Figuration von Räumen.

3 In the original German version, the English-language neologism "spacing" is used for this placement practice rather than the German word "räumen," for the latter has too strong of an association with "to empty" or "to vacate."

Ә OpenAccess. (c) 2021 Martina Löw, published by De Gruyter. (cc) BY-NC-ND This work is licensed under the Creative Commons Attribution-NonCommercial-NoDerivatives 4.0 License. 
in the context of typical spaces in modern society, specifically city and territory along with central relationships (urban-rural, space-time) (section 2). Drawing on this, it then introduces essential debates in spatial theory. These debates attest to the strong tradition of the sociology of knowledge within German-language sociology (section 3). The essay concludes by providing a brief outlook on the future of spatial sociology (section 4).

\section{Areas of Inquiry in Spatial Sociology}

\subsection{Urban and rural spaces}

The areas of inquiry in urban sociology and, in particular, the question concerning the development or reinforcement of social inequality through spatial structurations constitute a central research area in spatial sociology. Segregation, gentrification, neighborhoods, as well as urban-rural relationships are important spatial arrangements with serious consequences for the formation of social inequality. However, the spatial perspective is also relevant for analyzing cultural differences, for instance, according to ethnicity/race, gender, or sexuality.

Segregation refers to spatial structures that have developed such that "various social groups primarily live in certain zones within a city" (Hannemann, 2019: 53). Research on residential segregation focuses on investigating the inequitable distribution of groups of people according to residential districts. Häußermann and Siebel (2004) differentiate between forced and voluntary segregation. Segregation becomes problematic for residents when they feel that they have been forced. For example, this is the case when "ethnic colonies" (Ceylan, 2006) are formed in cities not because they are based upon the desire for spatial proximity to other immigrants from the same country of origin but rather because they develop as homogenous neighborhoods as a result of people finding dwelling spaces exclusively through these ethnically-based networks.

Above all the processes of gentrification reinforce segregation, meaning that renewal measures and/or changes in ownership in popular, often central urban districts entail increasing rents and force the departure of poorer segments of the population from these quarters (Breckner, 2010). However, this process by no means occurs in the same manner in all cities (Hoerning, 2016, on Brazilian cities). In the case of Berlin, for example, we find but little evidence of displacement towards the city's periphery. Rather, residents often remain in the same urban district but move to poorer-quality or smaller apartments to avoid paying higher rent. Whenever the supply of economical apartments in a district is exhausted, Berlin residents have so far still been able to find housing in other districts that are equivalent in character to their last place of residence (Bernt and Förste, 2018). Comparable courses of action are no longer an option in many other cities such as Hamburg and Munich (Breckner, 2010). 
In general, it can be shown that, in terms of income, homogenous districts have a negative effect on lower-income populations, whereas a heterogenous composition has a positive effect. Rabold and Beier (2013), for example, investigated the influence of neighborhood role models within urban districts in Hanover. They demonstrated that, in poorer urban districts with high potential for conflict, the probability that youth consider violence acceptable rises by a factor of 14. Jürgen Friedrichs (2014) showed that, in many German cities, the majority of households classified as poor are found in in urban districts that are not categorized as poor (i.e., less than $20 \%$ receive social-welfare benefits). This has positive effects insofar as it can be demonstrated that people from lower-income groups in these socially mixed districts are more frequently employed and develop fewer chronic illnesses than in comparable groups in poor urban districts. However, Talja Blokland (2008) warned against overvaluing such results since the proximity of resource-poor and resource-rich households does not necessarily lead to the development of mutual networks, let alone to the dissolution of class boundaries. Nina Schuster (2010) also showed that urban districts in Berlin with predominately poor populations can nevertheless be very culturally heterogenous-in terms of their ethnic composition, for instance, but also and above all through the encounters between the LGBT subculture and migrant cultures.

Since the spatial perspective considers placements alongside one another (just as the temporal perspective examines them one after another), it is unsurprising that spatial sociology treats relations between urban and rural areas as well as among cities as important areas of investigation.

Urban-rural comparisons are difficult in this respect since we are witnessing an increasing urbanization of society as a whole, so that urban and rural lifestyles are becoming more similar. What was once called a village is today often located on the fringes of a metropolitan area, providing a family location for commuters that is better described as a suburban area than a rural one (Frank, 2003). Nevertheless, on the level of lifestyles there certainly are recognizable differences between urban and rural areas in German-speaking countries. Considered within the terms of milieu analyses, there exist "the conventionalists in the tradition of the petite bourgeoisie, and family-oriented homebodies often living in precarious social conditions, typically in small towns and villages" (Otte and Baur, 2008: 110). According to Annette Spellerberg as well (2014), traditional and home-oriented lifestyles tend to be more prevalent in rural areas. Urbanization has an inherent tendency towards the centralization of cities, which cannot incorporate every place. Peripheral areas in particular suffer from weak economic structures and demographic change, significantly reducing opportunities for participation among the remaining population (Beetz, 2008).

Cities are increasingly being investigated through the lens of differentiated social formations and constructs of meaning (Berking and Schwenk, 2011; Löw, 2013). In work carried out under the heading of the "intrinsic logic of cities," intrinsic logic is understood as a heuristic. In this sense, intrinsic logic is not meant as a characteristic of a city that can be located, maintained, and cultivated; rather, the authors operate under the assumption that this intrinsic logic represents a perspective that is useful for 
politics, planning, and science in order to understand how cities shape life in a specific way, that is, how they influence ideas, constructions of reality, practices, or emotions (Frank et al., 2014). Among the many intrinsic-logic studies of cities, only one example shall be included here: When comparing how two middle-sized German cities react to problems (e.g., heavy traffic) given similar economic conditions, one of these cities (Frankfurt am Main) can be seen to habitually engage in discursively framing the problem as an "opportunity," as a means of demonstrating the capacity to effectively take action. By contrast, when the other city (Dortmund) is faced with the same problem, the assurance is routinely given that "it is better to deal with problems stoically because fixating on final solutions is generally to no avail” (Großmann, 2014: 67). Cities systematically differ from each other through their problem-solving strategies, time orientations, as well as through their emotional structures, for example (for a summary, cf. Löw, 2013; Frank et al., 2013). The question of intrinsic logic juxtaposes research on spatial structures that separate according to class or ethnicity with research on inclusion: shared experiences or collectively reproduced patterns of interpretation in cities and urban districts.

\subsection{Territory and flow}

In accordance with international research (e.g., Lefebvre, 1991; Harvey, 1982), spatial research in German-speaking countries also assumes a fundamental change in the spatial organization of the social during the establishment of modernity. With the change in imperial organizations, which also includes the adaptation of multiethnic empires to the "model of homogenizing nation-states starting in the 1860s" (von Hirschhausen and Leonhard, 2011: 402) and the extensive realization of an exclusionary conception of the territorial space of the state, modernity shows a tendency towards homogenizing its spaces (Lindemann, 2014: 152; Knoblauch and Löw, 2017). In addition to ethnic homogenization, this further ranges from the production of homogenous zones (children's playgrounds, pedestrian areas, historic urban cores, recreation zones, etc.) to the concept, familiar to every individual, that space may be described as a "container."

Against the background of the far-reaching globalization and digitalization of almost all areas of life, for many authors the question now arises as to how the social logic of territoriality-which, as the dominant logic, provided the structure for modernity up until the 1970s-is being overwritten, overlaid, transformed, or simply threatened in its dominant role by stronger network-like and more fluid socio-spatial logics. ${ }^{4}$ Another subject being debated is what consequences these developments will have for action in late-modern society.

4 Manuel Castells (1996) provided an important impetus for this debate. He described a rupture with modern, hierarchically organized society through the implementation of a "space of flows" starting in 
Andreas Reckwitz, for example, speaks of a "fundamental transformation of spatial structures" (2017: 8). Since the 1970s and '80s "the interchangeable spaces of classical modernity" (ibid.) have been transformed, and in their place now appear "recognizable individual places, each with its own atmosphere" (ibid). In classical modernity, space is "extensive and serial, as identical structures spread through it beyond local contexts, generating series of the same kind" (ibid.: 39). Classical modernity, he argues, transforms a container model of space into social reality. Activities are assigned to spaces. By contrast, today he sees singularized spaces being created "in which physical objects are arranged and bestowed with meaning and perceptual possibilities, such that they [...] are experienced as an inherent complexity with a specifically composed spatial density" (ibid.: 60f.). This spatial-structural conversion also appears at the level of cities. Classical modernity was already an urbanized society, but since the 1980s cities have come into focus as political centers. Cities distinguish themselves through their cultural uniqueness (or at least try to do so).

Hubert Knoblauch (2020) begins with the assumption that society today is formed through two "logics" simultaneously and in a thoroughly conflictual fashion. "The first logic of modernity is what we call a centralized figuration, which distinguishes itself by the differentiation of institutional specialized 'systems.' The second logic which becomes visible in communication society goes beyond postmodernity and refers to another figuration, which is characterized by relations and stands for the model of the network" (Knoblauch, 2020: 269). Translated into spatial terms, this means that territorial spatial forms (such as the nation-state, zone, camp, etc.) slide next to/over/under more fluid, more explicitly relational spatial forms such as networks, layers, clouds, channels, and so on (Löw, 2018). The concept of re-figuration is appropriate, Knoblauch continues, to avoid merely contrasting the two systems of order and to emphasize "that we are not concerned with a new 'epoch,' an epochal boundary, or even a threshold” (Knoblauch, 2020: 273). To the contrary, the primary characteristic of a late-modern society is rather that the principles of translocalization, networking, and communicativization and the principles of centralization may superimpose or oppose one another, at times in a conflictual, at other times in a mutually dependent manner. The principle of territorialization does not disappear, as demonstrated by increasingly fortified borders (Löw and Weidenhaus, 2017; Schönwald et al., 2018), but the de-hierarchization, networking, and permeability of borders meets hierarchization, centralization, and closure.

One hypothesis is that the constitution of space today, alongside territorial spatial structure and overwriting or undermining it, is also characterized by interdependent webs formed through translocalization and polycontexturalization (see Knoblauch and Löw, 2017). Translocalization means the embedding of social units such as fam-

the 1980s, which decisively transformed communication structures and thus brought about an enormous increase in the complexity of social relationships. 
ilies, neighborhoods, or religious communities in circulation and in this way simultaneously anchoring them in multiple places. Transnational linkages of places and circulation increases an awareness of the relatedness of each place to multiple others and thus overall an awareness that local conditions cannot be taken for granted. Polycontexturalization recognizes that spatial contexts of different scales and dimensions and on different levels must be made relevant at the same time. According to this hypothesis, this means that spaces become more meaningful figures more quickly and increasingly through simultaneous connections to various systems, fields, institutions, or rulesets as well as to the different spatial scales (global, supranational, national, urban, local) of society.

In general, beginning in the 1970s, an increase in worldwide networking and exchange was initially postulated through the concept of globalization. Subsequently, pluri-local connections between places were investigated under the heading of transnationalization (Weiß, 2017) and probed for spatial concentrations of communication (in contrast to the idea of a uniform flow) (Mau, 2010; Weiß, GLOBALIZATION AND TRANSNATIONALIZATION, this volume). It has been emphasized that globalization as the compression of the world through the interconnection of places results in "glocalization," implying an increasing significance of the local (Berking, 2006). According to Pries (2008) as well, this development has established a new transnational practice of permanent and continuous communication across a multitude of places. These changes also affect the subjective orientation of the actors, their spatial knowledge, and even their identity. For instance, socialization into an environment that is experienced as homogenous will increasingly be replaced by experiences of insularization (Zeiher and Zeiher, 1994; Reutlinger, 2004: 122). This transformation of subjective spatial orientation described as insularization will be reinforced through digitalization processes. This experience also transforms orientational knowledge, for example. The map will tend to be replaced with navigation systems. Under the current heading of smartification, localization practices are complemented (Schulz-Schaeffer and Lettkemann, 2018) by more sophisticated practices of asserting control by systematically linking mass data (from Amazon to the Smart City) (Baur, 2009).

\subsection{Space and time}

Even a cursory examination of the dynamic of change shows that the reorganization of spaces is not comprehensible without including a temporal perspective. Heike Delitz formulates this in reference to the philosophy of Henri Bergson as follows: "The social consists of constant change; precisely for this reason, collectives must consolidate themselves as the specific society that they are; they must institutionally establish themselves and categorize and position their subjects temporally and spatially" (2017: 75). They create a spatial and temporal order, which finds its individual expression through biography and habitat. In his book Soziale Raumzeit (Social Spacetime, 2015), Gunter Weidenhaus explains that humans interrelate constitutive forms of habitat and 
life history through biographical narratives. Weidenhaus reconstructed three types of life historicity: the linear type, the cyclical type, and the episodic type. In the context of this process of biographizing, he thus concludes that humans construct a historical life structure by setting the past, present, and future within a specific relationship. This relational determination follows one of the three aforementioned models. The author argues that this differs according to how a person exists spatially in the world, how the person positions habitats in relation to one another, whether and where the person determines his or her place therein, if the person establishes a concept of a center, and what roles borders, discretionary power, and identity-based linkages play within these.

The crux of the matter is that, if we examine the constitution of spaces in a time sample and the constitution of historicity in a spatial sample, then we find that linear biographizing is associated with a concentric constitution of space, episodic biographizing with a network-like constitution of space, and cyclical biographizing with an insular constitution of space. Should the suspicion be confirmed on closer examination that this close linkage of space and time cannot only be corroborated at the biographical level but also be shown to affect the social level, then this will give rise to entirely new perspectives. For example, this raises the question of whether differentiated spatial constructions-in political conflicts, among classes and ethnicities, between men and women, or by politics compared to economics-are also associated with varying conceptions of history, which, when taken into consideration, would open up new options for action (in this respect, see also Wehrheim, 2009, on spatial order and constructions of otherness).

\section{Spatial Theory as the Basis for Spatial Sociology}

Most recently, it has been primarily phenomenological, social-constructivist/communicative-constructivist, or even praxeological concepts that have incorporated the topic of space into the fundamental theories of German-language sociology (Schneider, SOCIAL THEORY, this volume). The critical initial thesis here is that spaces are socially constructed while they are at the same time constitutive of the social. This dual role of being both socially constructed and an inevitable precondition for social action is a feature that space shares with the felt body/physical body, for instance.

If we take this dual role seriously, then it follows that sociological theories must fundamentally grasp the spatial forms of ordering the social in such a way that spatial structures of action can also be understood independently of the era or of the respective culture or its specific local expression. When we analyze the fundamental forms of spatial action, this requires determining the specific spatial production of different (modern) societies (e.g., forms of segregation or urban-rural configurations). What is at issue in current debates within German-language spatial sociology is therefore the formulation of fundamental statements on the role of space for social action as well as the designation on this basis of the specifics of social spatial 
structures, in particular in modernity (or more precisely, in the different modernities). The most important theoretical contributions can be summarized as follows.

Gesa Lindemann (e.g., 2014 and 2017) focuses on the question of how social actors' relationships with their environment are spatially composed (Gugutzer/Peter, (FELT) BODY, SPORTS, MEDICINE, AND MEDIA, this volume). To this end, she draws on Plessner's theory of eccentric positionality (Plessner, 2019, orig. 1928) and phenomenological approaches to the felt body from Schmitz (1964-1980). The "felt-body self" is oriented towards other "felt-body selves" as well as towards the material realities of the environment via the felt body (centric positionality) (Lindemann, 2017: 12ff.). That is, its perception of its environment is mediated by its perception of its surroundings in relation to its own state. It experiences that it is affected by other feltbody selves and adjusts its behavior accordingly.

Eccentric positionality now recognizes the reflexivity of this felt body-environment relationship. Lindemann discusses the felt-body self, and not the subject, in order to emphasize that the environment and the individual's own state are not perceived in a detached manner but are experienced as being affected by events. From this felt-body focus, the result for sociology is that sociation can be analyzed "as a situated spatial-temporally structured performance of felt-body environmental references” (Lindemann: 2017:12). Considered in phenomenological terms, the felt body is different from the physical body and is the starting point for all local orientation (see also Merleau-Ponty, 1965). The concept of the physical body is used to denote the detached view (e.g., of science or medicine). It is three-dimensional in extent, and its position can be determined by location and on the basis of distances. Lindemann (2017: 14) sees the physical body as being located in a three-dimensionally defined container space. The felt body, by contrast, is here and now; its positioning is not always clear (e.g., as when waking up in the morning).

Considered from the standpoint of the felt body, there is (according to Lindemann or Schmitz) a surrounding space in the sense of an unstructured expanse (so-called extensive space). This is the actors' fundamental spatial reference. Directional space is to be distinguished from this. Moving outward from its center, the felt body orders this space particularly through structurations such as right/left, above/under, or in front/ behind. Physical action is oriented via this structuration, with the relationship between the felt-body self to the material environment being ordered in this way.

In the process, humans also experience their own felt body as being spatial. While the body as a whole can be tactilely perceived, the felt body is only perceptible in insular spatial locations (neck pain, upset stomach, etc.). In accordance with bodily sensations, spatial experience or communication with others also changes. While directional space is experienced beginning with the felt body, the physical body is positioned within what is called locational space (Ortsraum), defined through length, breadth, depth, and angular dimensions. References to the felt-body experience of directional space are irrelevant here, which is why Lindemann also speaks of "digital space" when referring to thoroughly structured locational space (Lindemann, 2014: 148). Dimensionally gauged space-dependent on seemingly objective observation, in 
which the physical body appears as positioned in an exact location-became established as the normative ideal only in the transition to modernity (Lindemann, 2017: 26).

If we want to answer the question, "in which spatial-temporal structures can which actors encounter or affect one another, and how?” (Lindemann, 2017: 28f.), then it is not only practical self-orientation through gestures, movements, and so on that are relevant but also the reflexivity of the felt body-environment relationships (eccentric positionality). Here, Lindemann speaks of a "triadic structure of reflexivity" (ibid.: 27). Through the experience of affect through the words, gestures, or glances of others, the circumstances of the relationship are reflected upon in consideration of the perspective of the other. Spatial action also occurs in relation to others, including the non-human other, by taking their perspective into account. Space, according to Christian Fritz-Hoffmann (2017), becomes "socially resonant space" on the basis of the relational dynamic. It is constitutive of all forms of communication and influences these so very effectively because we not only see the factors exerting this influence but also hear or smell them (see also Breidenstein, 2004).

Three other authors who in the past few years have decisively shaped the debate on space, namely, Silke Steets (e.g., 2015), Gabriela Christmann (e.g., 2016a; b), and Hubert Knoblauch (2020), agree with Gesa Lindemann's thesis that space can neither be understood exclusively as forming within the human (as a form of perception, cognitive act of association, etc.) nor as simply being a given reality in the world (which also excludes conceiving of space pragmatically as a reciprocal relationship between an existing spatial form and its subjective perception). Rather, the spatial being-in-the-world of humans with its concomitant relations constitutes the starting point for the spatial-theorizing of these authors as well.

In his conception of communicative constructivism, Hubert Knoblauch explains the absolute necessity of comprehending action itself as also being spatial, by referring to the finger-pointing of children. When the child is about nine months old, it begins to point at people and things, acting in a manner characterized by reciprocity. This is to say, through pointing it assumes that an other would also have the same experience were that other to occupy the same position. Moreover, pointing not only refers to the location of the person pointing but is also fundamentally oriented towards the position of the other to whom something is shown, such that the other can read from the pointing where and what is being indicated. The space that is by necessity opened up through the finger-pointing is therefore based upon bodily movement, the location of the person pointing, the location of the other, and the assumed reciprocity. For Knoblauch, pointing is only an example used to demonstrate how communicative action forms space, ${ }^{5}$ since this movement not only opens up a space

5 In the tradition of Max Weber, Knoblauch conceives of action as those acts of human doing or omission to which the actor attaches subjective meaning. Specification of such action as communicative action accounts for the fact that it is embodied as well as it is social in that it is reciprocally directed toward an other (and that its meaning derives from this relation). Knoblauch emphasizes that 
between the participating bodies of the actors but also extends it towards a third (that which is being pointed to). Through the indicative gesture, social reality is set in a spatial relationship.

Knoblauch starts (as do Steets and Christmann; see below) with the spatial concept developed by Löw (2016, orig. 2001) - a concept of space in the sense of a relational arrangement of living beings and social goods in places, which differentiates between spacing and acts of synthesis-in order to understand space in terms of relational action. However, in his theory of communicative action, Knoblauch develops the ego-world relationship into a triad. Spatial synthesis is not only an act of perception, imagination, and remembrance but also a form of communication. "Communicative action (...) proceeds from a triadic relation enabled by reciprocity. It is not the subject that is the primary reference point, rather the subject in a relation with the other. Space is not simply constituted in a dual relation between subject and object, or even between subjects" (Knoblauch, 2020: 209) but also from objectifications such as the pointing finger. Space emerges as an arrangement that "is formed in a social, or at least a socially constituted, relation, which is working, effecting, and affecting an objectivation or an objectification" (Knoblauch, 2020: 209). Following in the social-constructivist tradition (e.g., Berger and Luckmann, 1966), Knoblauch takes objectifications to (still) be fluid, processual phenomena linked to the physical body, such as gestures. Objectivations are reifications, which appear as if they were independent of the actions that produced them.

This elaboration demonstrates that we must take the spatial operations of acting subjects into account in erecting buildings, constructing objects, or positioning social goods and people (spacing). ${ }^{6}$ Spacing is not only to be understood as a relationship between humans and the object world (or also between objects, or between humans). According to Knoblauch, in its fundamental form, spacing is a triadic relationship through which the actions of the subjects (and their positions or places) remain dynamically related to one another.

Silke Steets (2015), who also works from a sociology-of-knowledge perspective on issues related to architecture and thus the construction of space, emphasizes that sociology was long only interested in immaterial objectivations (such as speech, roles, forms of knowledge). At the same time, the concept can also be transferred onto material objects, spaces, borders, and places. In her book, Der Sinnhafte Aufbau der gebauten Welt (Meaning in the Construction of the Built World), Steets expands upon the theoretical foundations of the sociology of knowledge to include the role of ma-

action is communicative for the additional reason that it becomes socially effective as mutually realized interaction between actors through objectifications. In other words, to move a stone or to press a red button is communicative because something is caused to happen that is observable as an effect in the shared environment of both subjects and thus appears meaningful.

6 When Knoblauch speaks of subjects, then in the sense of entities endowed with the capacity for subjectivity or for creating meaning. Processes of subjectification form as part of a reciprocal relationship, which is also a spatial relationship. 
teriality. She applies the terminology of externalization, objectification, and internalization (Berger and Luckmann, 1966) in order to demonstrate, first, that the material world is produced through collective action; second, that humans are faced with this (tangible) world of physical objects; and third, that the meaning of tangibility must enter into the subjective consciousness to become part of reality. Steets' core argument is that buildings (also meaning spaces) may be comprehended as "material objectifications," which, analogous to immaterial objectivations, represent an essential component of social reality.

Gabriela Christmann points out that a communicative exchange about spaces is inevitable in all societies (2016a: 7). However, particularly in modern, functionally differentiated societies it can be observed "that spatial conceptions and planned spatial designs are largely dealt with in a communicative manner, and indeed often among wider publics" (ibid.). She presents a method of "communicative space (re) construction" for discussion. Here she proposes (similarly to Knoblauch and Steets) to grasp space through both the relation between subjects and through their relationship to objectifications, objectivations, and their arrangements (Christmann, 2013). Subjects internalize spatial conceptions in ways that are influenced by their life history and cultural background (in an act of synthesis). These subjective interpretations of spatial reality are externalized through spatial action, that is, in occupying, designing, or communicating about spaces (spacing). It is precisely in communicative processes that subjective spatial interpretations congeal into collective conceptions of space. That is, space invariably becomes relevant as a nexus of interpretation and design (ibid.: 158f.) and, as a knowledge construct, is an object of investigation for the social sciences. The concept of spatial (re)construction as a tool for sociological analysis is intended to bring to the fore the processually generated meanings of spaces, which cannot be attributed to objectivations or subjective conceptions alone and can also always be changed (Christmann, 2016b: 90). This concerns everyday concepts (when we speak of ground, space, earth, landscape, or nature etc.; see also Henkel, 2017), structures perceived as typical (see Delitz, 2018), arrangements and changes to them (built structures, infrastructures, the planning of these; see Bartmanski and Fuller, 2018), as well as memories, habits, ruptures, and customs (see Frank, 2016).

The great significance of the sociology of knowledge within German-language spatial sociology entails a perspective that sees repetition and legitimation as the primary means of consolidating spatial arrangements. To the extent that it involves the body, the formation of spatial structures occurs as habitualization; in the material dimension, this formation takes place as the institutionalization of objectivations. Examples are the typical seating order around a negotiating table, the typical organization of rooms in a dwelling, or the typical securing of a national border, whereby the specific sensory character and design of these objectivations are also perfectly capable of directing the felt bodies.

This perspective on sensuousness and thus on affects as well as on the corporeality of spatial action is also adopted by Andreas Reckwitz, who approaches spaces from a praxeological perspective. Praxeological perspectives take "doing” as their 
starting point, which is understood in sociological terms as a models of practices emerging from repetition: "Yet these activities are not primarily considered as discrete and intentional acts by individual agents, but rather as recurring, spreading, and evolving patterns of practices which carry their agents and are at the same time carried (out) by them" (Reckwitz, 2012: 248). Through this perspective on doing, the human physical body emerges as the material anchoring for practices (on gendered bodily practices and space, see in particular Schuster, 2010, as well as Ruhne, 2003; Frank, 2003). Reckwitz expands the perspective focused on the material aspects of doing (see Schatzki, 1996) by starting with the assumption that every social practice is characterized by an "artefact-space structuration” (Reckwitz, 2012: 249; see also Müller and Reichmann, 2015). Artifacts are not experienced individually but only in spatial contexts. Doing is spatially embedded. At the same time, artifacts (and physical bodies) are components of each practice, which implies that social practices must be assumed to have a spatial dimension: "space depends on bodily movements as well as on the production, interpretation and usage of artefacts. But these artefacts can, once produced, form relatively stable and persistent spatial frameworks, for instance as architecture or as cultivated landscape” (Reckwitz, 2012: 252). Economic, political, pedagogical, and private practices are associated with corresponding spaces. They are formed from artifacts, and because artifacts are especially emotionally charged, according to Reckwitz, spaces are also strongly affect-laden.

Christmann, Knoblauch, Reckwitz, and Steets all agree that space in essence exhibits three dimensions: the social dimension of the relation, the material-bodily dimension of the objectivation or the artifact, and the subjective dimension, which Christmann conceives more strongly in terms of the conception of space and the three others more in sensory terms as experience, affect, and reference. In none of these approaches is space used as a metaphor but rather as a theoretical concept consistently directed towards the question of "where in the world" (Löw and Weidenhaus, 2017).

\section{Outlook}

The action-theoretical perspective in the widest sense (here also including a praxeological and a phenomenological approach) that is being formulated in Germanlanguage spatial sociology makes it possible to understand social processes and the social actors themselves in spatial terms. This avoids juxtaposing individuals on the one side with spaces on the other. Instead, spaces are generated through relational (inter)action between things and living beings. Spaces become cities with their own intrinsic logic, evolving territories, segregated urban spaces, and so forth. Spaces emerge through action that integrates things and physical bodies. Just which spatial arrangements are reproduced, habituated, and institutionalized through routinized action will always remain a question to be explained empirically. 
Formulating and discussing theories of space, or of spatial action, will occupy sociology for some time to come. It is after all not only a matter of mere elaboration but rather, as Reckwitz correctly stated, it "demands us to rethink our general conceptual framework for analysing the social and to overcome the defects of classical social theory" (2012: 242). There is a great amount of empirical evidence showing that the spatial order of the social (e.g., transformation of the "territory" paradigm, digitalization, changes in the urban-rural relationship) has fundamentally changed in recent decades. The major open research question for spatial sociology is which new spatial arrangements this development has brought about (approaches here are, e.g., the network: Castells, 1996; territorialization as movement: Schroer, 2017: 142; fluid spaces: Law and Mol, 2001; etc.). Little research has so far been done on how change occurs and with what consequences (for whom and where).

\section{References}

Bartmanski, D.; Fuller, M. Reconstructing Berlin: Materiality and Meaning in the Symbolic Politics of Urban Space. City 2018, 22, 202-219.

Baur, N. Measurement and Selection Bias in Longitudinal Data. A Framework for Re-Opening the Discussion on Data Quality and Generalizability of Social Bookkeeping Data. Historical Social Research 2009, 34, 9-50.

Beetz, S. Peripherisierung als räumliche Organisation sozialer Ungleichheit. In Peripherisierung eine neue Form sozialer Ungleichheit? Materialien der Interdisziplinären Arbeitsgruppe:

Zukunftsorientierte Nutzung ländlicher Räume - Landlnnovation. Materialien Nr. 21;

Barlösius, E., Neu, C., Eds.; Berlin-Brandenburgische Akademie der Wissenschaften: Berlin, 2008; pp 7-16.

Berger, P.; Luckmann, T. The Social Construction of Reality; Anchor: New York, 1966.

Berking, H. Raumtheoretische Paradoxien im Globalisierungsdiskurs. In Die Macht des Lokalen in einer Welt ohne Grenzen; Berking, H., Ed.; Campus: Frankfurt a.M./New York, 2006; pp 7-22.

Berking, H.; Schwenk, J. Hafenstädte. Bremerhaven und Rostock im Wandel; Campus: Frankfurt a.M./New York, 2011.

Bernt, M.; Förste, D. The Black Box of Displacement: Do People Remain in their Neighborhoods or Relocate to the Periphery? In Gentrification and Resistance: Researching Displacement Processes and Adaption Strategies; Helbrecht, I., Ed.; Springer VS: Wiesbaden, 2018; pp 37-57.

Blokland, T. Gardening With a Little Help From Your (Middle Class) Friends. Bridging Social Capital Across Race and Class in a Mixed Neighbourhood. In Networked Urbanism. Social Capital in the City; Blokland, T.; Savage, M., Eds.; Ashgate: Aldershot, 2008; pp 147-170.

Bourdieu, P. Outline of a Theory of Practice; Cambridge University Press: Cambridge, 1977.

Breckner, I. Stadtentwicklung. Gentrifizierung im 21. Jahrhundert. Aus Politik und Zeitgeschichte 2010, 17, 27-32.

Breidenstein, G. KlassenRäume - eine Analyse räumlicher Bedingungen und Effekte des Schülerhandelns. Zeitschrift für qualitative Bildungs-, Beratungs- und Sozialforschung 2004, 1, 87-107.

Castells, M. The Rise of the Network Society; Blackwell: Oxford, 1996.

Ceylan, R. Ethnische Kolonien. Entstehung, Funktion und Wandel am Beispiel türkischer Moscheen und Cafés; Springer VS: Wiesbaden, 2006. 
Christmann, G. Raumpioniere in Stadtquartieren und die kommunikative (Re-) Konstruktion von Räumen. In Kommunikativer Konstruktivismus. Theoretische und empirische Arbeiten zu einem neuen wissenssoziologischen Ansatz; Keller, R.; Knoblauch, H.; Reichertz, J., Eds.; Springer VS: Wiesbaden, 2013; pp 153-184.

Christmann, G. Einleitung zur kommunikativen Konstruktion von Räumen. In Zur kommunikativen Konstruktion von Räumen: Theoretische Konzepte und empirische Analysen; Christmann, G., Ed.; Springer VS: Wiesbaden, 2016a; pp 7-25.

Christmann, G. Das theoretische Konzept der kommunikativen Raum(re)konstruktion. In Zur kommunikativen Konstruktion von Räumen: Theoretische Konzepte und empirische Analysen; Christmann, G., Ed.; Springer VS: Wiesbaden, 2016b; pp 89-117.

Delitz, H. Das soziale Werden und die sozietalen Zeiten und Räume. Bergsonianische Konzepte der Gesellschaftstheorie; In Raum und Zeit. Soziologische Beobachtungen zur gesellschaftlichen Raumzeit. Zeitschrift für Theoretische Soziologie. 4. Sonderband; Henkel, A.; Laux, H.; Anicker, F., Eds.; Beltz Juventa: Weinheim/Basel, 2017; pp 74-96.

Delitz, H. Architectural Modes of Collective Existence: Architectural Sociology as a Comparative Social Theory. Cultural Sociology 2018, 12, 37-57.

Durkheim, E. The Elementary Forms of the Religious Life: A Study in Religious Sociology; George Allen and Unwin: London, 1915.

Foucault, M. Discipline and Punish: The Birth of the Prison; Penguin Books: London, 1991 [1975].

Frank, Su. Stadtplanung im Geschlechterkampf. Stadt und Geschlecht in der Großstadtentwicklung des 19. und 20. Jahrhunderts; Leske \& Budrich: Opladen, 2003.

Frank, Sy. Wall Memorials and Heritage: The Heritage Industry of Berlin's Checkpoint Charlie; Routledge: London, 2016.

Frank, Sy.; Schwenk, J.; Steets, S., Weidenhaus, G. Der aktuelle Perspektivenstreit in der Stadtsoziologie. Leviathan Berliner Zeitschrift für Sozialwissenschaft 2013, 2, 197-223.

Frank, S.; Gehring, P.; Griem, J.; Haus, M., Eds.; Städte unterscheiden lernen. Zur Analyse interurbaner Kontraste; Campus: Frankfurt a.M. /New York, 2014.

Friedrichs, J. Kontexteffekte von Wohngebieten. In Kölner Zeitschrift für Soziologie und Sozialpsychologie 2014, 66, 287-316.

Fritz-Hoffmann, C. Grundzüge eines erweiterten Berührungsbegriffs. Soziale Welt 2017, 68, 199-224.

Giddens, A. The Constitution of Society; University of California Press: Berkeley/Los Angeles, 1984.

Großmann, A.; Wendungen der Dringlichkeit. In Städte unterscheiden lernen. Zur Analyse interurbaner Kontraste; Frank, S.; Gehring, P.; Griem, J.; Haus, M., Eds.; Campus: Frankfurt a.M. /New York, 2014; pp 43-68.

Hannemann, C. Stadtsoziologie. In Handbuch Sozialraum. Grundlagen für den Bildungs- und Sozialbereich (2nd ed.); Kessl, F.; Reutlinger, C., Eds.; Springer VS: Wiesbaden, 2019; pp 45-68.

Harvey, D. The Limits to Capital; Blackwell: Oxford, 1982.

Häußermann, H.; Siebel, W. Stadtsoziologie. Eine Einführung; Campus: Frankfurt a M./New York, 2004.

Henkel, A. Zur Differenzierung und Verdinglichung von Boden, Raum und Pflanzenernährung in der modernen Gesellschaft; In Raum und Zeit. Soziologische Beobachtungen zur gesellschaftlichen Raumzeit. Zeitschrift für Theoretische Soziologie. 4. Sonderband; Henkel, A.; Laux, H.;

Anicker, F., Eds.; Beltz Juventa: Weinheim/Basel, 2017; pp 97-125.

Hoerning, J. "Megastädte" zwischen Begriff und Wirklichkeit. Über Raum, Planung und Alltag in großen Städten; transcript: Bielefeld, 2016.

Knoblauch, H. The Communicative Construction of Reality; Routledge: London, 2020.

Knoblauch, H.; Löw, M. On the Spatial Re-Figuration of the Social World. Sociologica 2017, 2. 
Law J.; Mol A. Situating Technoscience: An Inquiry Into Spatialities. Environment and Planning 2001, 19, 609-621.

Lefebvre, H. The Production of Space; Blackwell: Malden, 1991 [1974].

Lindemann, G. Weltzugänge. Die mehrdimensionale Ordnung des Sozialen; Velbrück: Weilerswist, 2014.

Lindemann, G. Die Raumzeit der Akteure; In Raum und Zeit. Soziologische Beobachtungen zur gesellschaftlichen Raumzeit. Zeitschrift für Theoretische Soziologie. 4. Sonderband; Henkel, A.; Laux, H.; Anicker, F., Eds.; Beltz Juventa: Weinheim/Basel, 2017; pp 10-39.

Löw, M. The City as Experiential Space: The Production of Shared Meaning. International Journal of Urban and Regional Research 2013, 37, 894-908.

Löw, M. The Sociology of Space; Palgrave Macmillan: New York, 2016 [2001].

Löw, M. Vom Raum aus die Stadt denken. Grundlagen einer raumtheoretischen Stadtsoziologie; transcript: Bielefeld, 2018.

Löw, M.; Weidenhaus, G. Borders That Relate: Conceptualizing Boundaries in Relational Space. Current Sociology 2017, 65, 553-570.

Mau, S. Social Transnationalism. Lifeworlds beyond the Nation State; Routledge: London, 2010.

Merleau-Ponty, M. Phenomenology of Perception; Routledge \& Kegan Paul: London, 1965 [1945].

Müller, A.; Reichmann, W., Eds. Architecture, Materiality and Society: Connecting Sociology of Architecture with Science and Technology Studies; Palgrave Macmillan: New York, 2015.

Otte, G.; Baur, N. Urbanism as a Way of Life? Räumliche Variationen der Lebensführung in Deutschland. Zeitschrift für Soziologie 2008, 37, 93-116.

Pfeil, E. Das Großstadtkind; Reinhardt: Munich/Basel, 1965.

Plessner, H. Organic Life and the Human: An Introduction to Philosophical Anthropology; University Press: Fordham, 2019 [1928].

Pries, L. Die Transnationalisierung der sozialen Welt. Sozialräume jenseits von Nationalgesellschaften; Suhrkamp: Frankfurt a.M., 2008.

Rabold, S.; Baier, D. Sozialräumlicher Kontext und Jugenddelinquenz. Zum Einfluss von Stadtteileigenschaften auf gewalttätiges Verhalten von Jugendlichen am Beispiel Hannover. In Städtische Armutsquartiere - Kriminelle Lebenswelten?; Oberwittler, D.; Rabold, D.; Baier, S., Eds.; Springer VS: Wiesbaden, 2013: pp 169-191.

Reckwitz, A. Affective Spaces: A Praxeological Outlook. Rethinking History 2012, 16, 241-258.

Reckwitz, A. Die Gesellschaft der Singularitäten. Zum Strukturwandel der Moderne; Suhrkamp: Berlin, 2017 [The Society of Singularities; Polity Press: Cambridge/Medford, 2020]

Remy, J.; Voye, L. Ville, ordre et violence: formes spatiales et transaction sociale; Presses Universitaires de France: Paris, 1981.

Reutlinger, C. Die Notwendigkeit einer neuen Empirie der Aneignung - der Ansatz der Bewältigungskarten. In “Aneignung” als Bildungskonzept der Sozialpädagogik; Deinet, U.; Reutlinger, C., Eds.; VS: Wiesbaden, 2004; pp 121-135.

Ruhne, R. Raum, Macht, Geschlecht. Zur Soziologie eines Wirkungsgefüges am Beispiel von (Un) Sicherheiten im öffentlichen Raum; Leske und Budrich: Opladen, 2003.

Schatzki, T. Social Practices: A Wittgensteinian Approach to Human Activity and the Social; Cambridge University Press: Cambridge, 1996.

Schmitz, H. System der Philosophie; Bouvier: Bonn, 1964-1980.

Schönwald, A.; Spellerberg, A.; Weber, F. Grenzen - Identitäten - Heimat: Theoriegeleitete Annäherungen an Konstrukte und Konzepte im “grenzüberschreitenden” Kontext. In Border Futures - Zukunft Grenze - Avenir Frontiére. Arbeitsbericht der ARL Nr. 20; Pallagst, K.; Hartz, A.; Caesar, B., Eds.; Verlag der ARL: Hannover, 2018; pp 130-142. https://shop.arl-net. de/media/direct/pdf/ab/ab_020/ab_020_gesamt.pdf (Retrieved Nov 23, 2018).

Schroer, M. Geosoziologie im Zeitalter des Anthropozäns; In Raum und Zeit. Soziologische Beobachtungen zur gesellschaftlichen Raumzeit. Zeitschrift für Theoretische Soziologie. 
4. Sonderband; Henkel, A.; Laux, H.; Anicker, F., Eds.; Beltz Juventa: Weinheim/Basel, 2017; pp 126-152.

Schulz-Schaeffer, I.; Lettkemann, E. Lokative Medien. Inklusion und Exklusion in öffentlichen Räumen. TU Berlin, Fachgebiet Technik- und Innovationssoziologie; Working-Paper: TUTS-WP-1-2018, 2018. www.ts.tu-berlin.de/fileadmin/i62_tstypo3/TUTS-WP-1-2018_ LokativeMedien.pdf (Retrieved Nov 23, 2018).

Schuster, N. Andere Räume. Soziale Praktiken der Raumproduktion von Drag Kings und Transgender; transcript: Bielefeld, 2010.

Simmel, G. The Sociology of Space. In Simmel on Culture; Frisby, D.; Featherstone, M., Eds.; Sage: London, 1997 [1903]; pp 137-170.

Spellerberg, A. Was unterscheidet städtische und ländliche Lebensstile? In Urbane Ungleichheiten; Berger, P.; Keller, C.; Klärner, A.; Neef, R., Eds.; Springer VS: Wiesbaden, 2014; pp 199-232.

Steets, S. Der sinnhafte Aufbau der gebauten Welt. Eine Architektursoziologie; Suhrkamp: Berlin, 2015.

von Hirschhausen, U.; Leonhard, J. Zwischen Historisierung und Globalisierung: Titel, Themen und Trends der neuen Empirie-Forschung. Neue Politische Literatur 2011, 56, 389-404.

Wehrheim, J. Der Fremde und die Ordnung der Räume; Barbara Budrich: Opladen, 2009.

Weidenhaus, G. Soziale Raumzeit; Suhrkamp: Berlin, 2015.

Weiß, A. Soziologie globaler Ungleichheiten; Suhrkamp: Berlin, 2017

Zeiher, H.; Zeiher, H. Orte und Zeiten der Kinder. Soziales Leben im Alltag von Großstadtkindern; Beltz Juventa: Weinheim, 1994. 